\title{
The Butler Affair and the Geopolitics of Identity
}

Gerry Kearns, Department of Geography, National University of Ireland Maynooth, Maynooth, Kildare, Ireland; email: gerry.kearns@nuim.ie

Paper and references 9899 words 


\section{The Butler Affair and the Geopolitics of Identity}

Abstract. In the wake of the Global War on Terror, Judith Butler has written of the 'precarity' of life, of the inevitable vulnerability of one's life in the face of the actions of strangers. Refusing to accept this, the United States has a developed a form of nationalism that claims invulnerability for its citizens while treating as expendable the lives of distant others who even unwittingly associate with those who threaten the US homeland. Butler has extended this set of criticisms to Israel's policy towards Palestinian people and in doing so has been criticized as Antisemitic. She has engaged with these questions about Jewish identity, nationalism, and toleration through an engagement with writers of the Jewish diaspora developing what we may describe as a geopolitical perspective on identity. The value of such a perspective was given ironic point by the public controversy over the award to Butler of the Adorno Prize in 2012. This article argues also that in responding to the biopolitics of the Global War on Terror, Butler has also elaborated some of the geopolitical bases of identity and in doing so has illuminated the academic politics of the current Boycott, Divestment and Sanctions campaign called for by many institutions of Palestinian civil society.

\section{The Adorno Prize}

In Frankfurt on 11 September 2012, for her contributions to critical social theory, Judith Butler was honoured with the Theodor W. Adorno Prize. While the citation noted that current discussions of gender, the subject, and morality, and even some parts of modern literature, film, theatre and the visual arts, have been decisively shaped by Butler's work on Identity and the Body (City of Frankfurt, 2012), the protests against the award were both about and illuminated by her most recent work on what we might call the geopolitics of identity. On the face of it, Butler was an entirely appropriate choice having 
engaged with the work (Butler, 2005) and preoccupations of Theodor Adorno (1903-63). In her acceptance speech, Butler (2012a, page 10) took up Adorno's claim that "the quest for a good life is a quest for the right form of politics."

Butler developed the argument in two ways. She suggested that the vital aspects of the question were not explicated by Adorno. More particularly she proposed, as she had in Precarious Life (Butler, 2004a) and in Frames of War (Butler, 2010a), that in modern societies, some lives are so devalued that mourning their loss is foreclosed (Debrix, 2011). Accepting what Butler (2012a, page 15) calls "precarity", that is our interdependence and our vulnerability before others, animates our search for mutually "liveable lives", recalling to us that our individual good life presumes communal support for, and validation of, a diversity of lives and life choices. In the face of institutional violence, the flourishing of diverse people is simply impossible and many are denied the possibility of a good life, leading Butler to the paradoxical question of her talk: "Can one lead a good life in a bad life?” Reflecting upon Primo Levi's (1919-87) account of his survival of Auschwitz, Butler (2012a, page 12) concluded that even "under conditions of extreme peril and heightened precarity, the moral dilemma does not pass away; it persists precisely in the tension between wanting to live and wanting to live in a certain way with others." For Butler, then, the politics of a good life are about biopolitics, non-violence, and the preconditions of mutual flourishing.

The second way that Butler engages Adorno's notion of politics is through an examination of resistance. Adorno had responded to the direct action of students in 1967-8 with the angry denial that he "had ever supplied the model for any acts or political actions whatever" (Müller-Doohm, 2005, page 477). Adorno worried that in attacking the German state as fascist, the students would produce the kind of authoritarian reaction that really would install what they claimed to be attacking (Kundani, 2009, page 58). In short: "At the present moment, no higher form of society is 
concretely visible" (Adorno, 1991, page 202). In these circumstances thinking was its own form of resistance and capable, he thought, of sublimating anger: "Such thought is happiness, even where unhappiness prevails" (Adorno, 1991, page 203). Against this, Butler insisted upon the social character of resistance, proposing that in acting together within a social movement we improvise new forms of community.

These issues of biopolitics and of the utopian potential of new social movements are central to the work of Butler and, as Eva Illouz (2012) insisted, "[n]o one can ignore her staggering influence in renewing the critical theory of Theodor Adorno," but, Illouz went on to criticize Butler for her "unworthy" political positions before insisting that these should not disqualify her from being honoured with the Adorno award since "there is no direct continuity between Butler's analysis [...] and her political positions." Other commentators were less charitable arguing that a prize named in honour of a Jewish scholar forced to leave Germany by Nazi persecution should not be given to someone critical of Israel.

Butler was attacked for supporting the Boycott, Disinvestment and Sanctions (BDS) campaign, for identifying Hamas and Hezbollah as part of the global Left by virtue of their opposition to Israeli colonialism, and for the alleged anti-Semitism of her criticisms of Israeli state violence. In the name of Scholars for Peace in the Middle East, four writers insisted that "Who boycotts Israel cannot be an Adorno-laureate" (Keuntzel, Schumann et al, 2012). Alex Joffe (2012) lambasted Butler's comments about Hamas and Hezbollah as support for "religious fascism," while Charles Small, founder and director of the Institute for the Study of Global Antisemitism, was more extreme asserting that "[t]his supporter of reactionary, xenophobic, sexist homophobes, who are on the payroll of the Iranian regime, will actually be killing innocent Syrians as she accepts her 'reward"' (Weinthal, 2012a). Stephen J. Kramer, styled by the Jerusalem Post as the General Secretary of Germany's Jewish community, was appalled to find that the city of Frankfurt "lacks 
the moral firmness necessary" to refuse to "separate Butler's contribution to philosophy from her moral depravity" (Weinthal, 2012b). From 20 August to 11 September an online campaign protesting the award gathered 123 supporters (Anon, 2012).

\section{The Politics of Philosophy}

Despite some well-meaning attempts to separate Butler's politics from her academic work, the connections are evident and important. Her doctoral research was on French philosophers' reworking of Hegel's account of the "relation between desire and recognition" (Butler, 2012b, page xx). Yet her turn to philosophy had personal roots and she writes that she "wasn't sure that either my own gender or my own sexuality $[\ldots]$ were going to allow me to be immune from social violence of various forms" (Butler, 1999a, page 195). She speaks of growing up in Cleveland, Ohio, and of "understanding something of the violence of gender norms: an uncle incarcerated for his anatomically anomalous body deprived of family and friends, living out his days in an 'institute' in the Kansas prairies" (Butler, 1999b, page xix). From Hegel she took the lesson that desires require social recognition and ever after Butler attends to the many ways that this recognition gets foreclosed.

In Gender Trouble, she remarked that heterosexist paradigms of womanhood limit lesbian identification within feminism. She argues that any attempt to specify the essence or limits of a distinct subject, such as Woman, closes down a negotiation that is collective and continuous, political and cultural. Drag, for example, reminding us that "the gendered body is performative" undermines any understanding of gender as a natural binary (Butler, 1999a, page 173). Gender, then, is always a repeat performance and in endless duplication copies can drift. Butler credited this insight to her reading of Jacques Derrida's (1930-2004) essay on Franz Kafka’s (1883-1924) parable, “Before the Law” (1915). Kafka's story of the man from the country who is excluded from the place of the 
law by a doorkeeper telling him that a power will be unleashed were he to challenge the injunction to not enter the place of the law, enjoys the pun on "before" (both in front of, and in advance of it happening). The law is instantiated by obedience but is otherwise unspecific and thus Derrida asks "[i]f the law is fantastic, if its original site and occurrence are endowed with the qualities of a fable [...]" (Derrida, 1992, page 199). The man "attributes a certain force to the law" and this anticipation of the force of the Law is enough to enforce it (Butler, 1999b, page xiv). Performance repeats copies, with no censorship from an origin.

\section{Jewishness, Zionism, and Antisemitism}

The subtitle of Gender Trouble was "Feminism and the subversion of identity," suggesting one way of using its insights to respond to her current critics. We might ask whether there is a secure grounding for all forms of Jewishness or whether there are not, rather, practices and performances which are signified differently from place to place, and situation to situation. We might think about the violence that has been done on too many occasions in the name of fixing such an identity. We might reflect upon the many ways someone might be Jewish: by genealogy, by religious practice, by cultural affiliation, by residence. We might recall that people with a Jewish identity, understood in any one of these ways, will also have very many other strings to their bow. For some of them, their sexuality, gender expression, political affiliation, national identity, or kinship may be inflected by their Jewish identity to a greater or lesser degree. There are conservative Jewish people and progressive Jewish people, French Jewish people and Israeli Jewish people, gay Jewish people and celibate Jewish people, Jewish fathers and Jewish sistersin-law, Orthodox Jews and atheist Jewish people, Zionist and anti-Zionist Jewish people. This multiplicity of identifications is overlain by the legacies of a historical geography of violence, nationalisms, racisms, and imperialisms. 
Many criticisms of Butler conflate all the various categories of Jewishness and identify this singular Jewish identity uniquely with Israel. For some, Butler's position is an example of a new antisemitism. In a speech in 1972 Abba Eban (1915-2002), then Israel's Foreign Minister, attacked left-wing figures in the United States for their harsh judgements upon Israeli foreign policy: "Let there be no mistake: the new left is the author and the progenitor of the new anti-Semitism. [...] The new anti-Semitism says that the right to establish and maintain an independent national sovereign state is the prerogative of all nations, so long as they happen not to be Jewish" (Eban, 1973). On 10 November 1975, the General Assembly of the United Nations adopted Resolution 3379, determining that "Zionism is a form of racism and racial discrimination" (UN 1975). The week before, Eban (1975) had excoriated the United Nations as "on the way to becoming the world center of anti-Semitism," attacking the "values, ideals and articles of faith revered by the Jewish people across the centuries," and he asserted that: "There is, of course, no difference whatever between anti-Semitism and the denial of Israel's statehood." In his speech of 1972 Eban (1973) reserved particular scorn for Jewish critics of Israel, proposing that they suffered from a "basic complex [...] of guilt about Jewish survival."

Butler responded to this style of criticism when she took to task, Lawrence Summers, then president of Harvard University, for a speech to Harvard students and faculty in which, identifying the boycott campaign as one of his targets, he remarked that while "profoundly anti-Israel views are increasingly finding support in progressive intellectual communities. Serious and thoughtful people are advocating and taking actions that are anti-Semitic in their effect if not their intent" (Summers, 2002). In replying, Butler challenged the assumptions of those who see all criticism of Israel as inherently Antisemitic: "A criticism of Israel is not the same [...] as a challenge to Israel's existence $[\ldots]$. A challenge to the right of Israel to exist can be construed as a challenge 
to the existence of the Jewish people only if one believes that Israel alone keeps the Jewish people alive or that all Jews invest their sense of perpetuity in the state of Israel in its current or traditional forms" (Butler, 2003).

Both themes of Butler's acceptance speech are pertinent: on one hand, the significance of biopolitics; and, on the other, the importance of new social movements in forging fresh ways of recognising others. Even the attacks on Butler repeat these themes, for one charge is that in attacking Israel, Butler and others imperil the physical survival of Jewish people, while a second is that movements such as the boycott, cultivate a hatred of Jewish people and make of Israel a pariah among nations.

\section{Unaccounted Deaths}

From her earliest engagement with the work of Michel Foucault (1926-84), Butler attended to vitalism (Kearns and Reid-Henry, 2009). She noted both that Foucault (1990, page 145) wrote of the replacement of a juridical order by a war economy as shifting state regulation towards, "life more than the law," and, relatedly, that, in her words, Foucault understood some forms of resistance to juridical power as themselves a release of "life-affirming energy" (Butler, 2012b, page 227). Much of Butler's work examines these relations between law and life. Her conclusions return us to the unknown, remembered gate of Butler's own Jewish identity and they do so, in part, because we engage politically from within and not outside relationships that already implicate us. When Karl Marx (1818-83) penned his apothegm of historical materialism, he gave the human subject precisely this sort of ideological predicate for, although he insisted that people "make their own history, but not of their own free will; not under circumstances they themselves have chosen but under the given and inherited circumstances with which they are directly confronted," he went on to particularize these un-chosen circumstances as the "tradition of the dead generations" which "weighs like a nightmare on the minds 
of the living” (Marx, 1973, page 146). Butler brings the psychoanalytic perspective anticipated by Marx's formulation of his own materialism.

Repression and foreclosure are two of the ways that Butler shows psychic life relating to norms. Under repression one internalizes an injunction to repeat no more a given behaviour, whereas under foreclosure one internalizes an injunction to never ever try a given behaviour. One may mourn the thing lost to repression but one can respond to foreclosure only with melancholia, since the "loss cannot be grieved because it cannot be recognized as loss, because what is lost never had any entitlement to existence" (Butler, 1997b, page 24). One may even relish the destruction of the object one cannot mourn. The foreclosure of same-sex love defines gender, such that "homosexual desire [...] panics gender" (Butler, 1997b, page 136). Gay panic begins as early guilt about same-sex feelings and this "sublimation of homosexuality" means, as Butler (1997a) reads Freud, that the social side of each person's ego-ideal incorporates an identification with a community of others all understood as offering risky provocation to a love that none dare speak. This is what Eve Kosofsky Sedgwick (1950-2009) described as the homosociality of the closet (Sedgwick, 1985; 1990).

It is in the context of same-sex love, that Butler developed the argument about foreclosure, desire, and murderous fantasy but related processes occur with respect to other important dimensions of identity. Butler has spoken of her own Jewish background. Her "mother's uncles and aunts were all killed in Hungary" during the Holocaust, her "parents were practicing Jews," and her Jewishness "was important for me. I went to Hebrew school. But I also went after school to special classes on Jewish ethics because I was interested in the debates" (Aloni, 2010). Butler agrees that her obsessions include "melancholy, mourning, conscience, guilt, terror, and the like," and she understands this focus as "what happens when a Jewish girl with a Holocaustal 
psychic inheritance sits down to read philosophy at an early age" (Butler, 2004b, page 195). She has more recently taken up these matters with respect to the state of Israel.

In Precarious Life, Butler drew many parallels between the foreign policy stances of Israel and the US. These parallels are so strong that an argument about mourning and violence that was developed as criticism of the US became at many points critical of the policies of the state of Israel. Butler suggested that powerful states must take “responsibility for the global conditions of justice" (Butler, 2004a, page 17). In this respect, the response of the US after the crimes of 9/11 was, she argued, particularly bad because "the United States has effectively responded to the violence done against it by consolidating its reputation as a militaristic power with no respect for lives outside of the First World” (Butler, 2004a, page 17). In legitimating its violent practices, the US makes extravagant use of terrorist as an accusation and thus "positions itself exclusively as the sudden and indisputable victim of violence," and this "injury authorizes limitless aggression against targets that may or may not be related to the sources of [its] suffering" (Butler, 2004a, page 4). Terrorism relates not to the consequences or intentions of violence but rather to its perpetrator and target. Violence by states is not understood as terrorist whereas violence against states by non-states is. Terrorism, then, is "a way of characterizing violence waged by, or in the name of, authorities deemed illegitimate by established states," and in this connection Butler turned to Israel where: "As a result, we have the sweeping dismissal of the Palestinian Intifada as 'terrorism' by Ariel Sharon, whose [own] use of state violence to destroy homes and lives is surely extreme" (Butler, 2004a, page 88).

In Frames of War, Butler argued that Israel's policy towards Palestinian people “disowns a common exposure to violence, by establishing the territory of Gaza as an open-air prison, as radically, if not permanently, unprotected and exposed to destruction at the same time that Israel phantasmically walls itself off from that possibility" (Butler, 
2010b, page xxv). With respect to Gaza, Butler follows successive reports of the United Nations Commission on Human Rights in insisting that Israel recognize its obligations as the occupying power (UN, 2001). In this context, Foucault's description of a war economy as regulating life seems apposite. By restricting imports to Gaza, Butler (2010b, page xxiii) insisted that Israel was responsible for "starvation in Gaza." Frames of W ar was written in the aftermath of Israel's Operation Cast Lead in Gaza (27 December 2008-18 January 2009). At the time there were perhaps one million Israeli border residents at risk from rocket attacks launched from Gaza and about one-and-half million Palestinian residents in Gaza. In Gaza, from January 2005 to the end of October 2008, 1,333 Palestinians were "killed in direct conflict related incidents," including 233 children, and, over the same period, 27 Israelis were killed in Gaza and 54 in Israel, including 7 children (UN, 2008).

It was not only the grotesque dis-proportionality which concerned Butler but also Israel's attempt to disown the civilian nature of the targeted people and facilities. While some Hamas were military many others were involved in civilian administration, yet Israel claimed to be able to "name more than 700 Hamas militants killed in the fighting" (Butler, 2010b, page xxii). In related fashion, other civilians were discounted because being used by Hamas to shield itself, so that these unfortunates might be considered not primarily as perhaps children but, observed Butler (2010b, page xxiv), as "bits of armament, military instruments and materiel, aiding and abetting an assault on Israel." Once again we see the category terrorist spread widely, "defined in ways that are vague and overly inclusive," and effectively devaluing certain types of lives in comparison to others, a fatal biopolitics (Butler, 2010a, page 156). 


\section{Learning from Social Movements}

In describing the fatal biopolitics of the war on terror and of the Israeli policies towards Gaza, Butler draws the sort of public criticism that issued in the campaign to have her denied the Adorno Prize. She describes the accusation that she is anti-Semitic as one "with profound psychological consequences," imposing upon her an "unbearable, stigmatized mode of identification," but one that she says "must be weathered" in order that public discussion of Israel not be unreasonably curtailed (Butler, 2004a, page 127). Butler (2004a, page 127) says that "a certain collective courage" is needed to stand up to these attacks; that "this can only be done with the support of other actors, others who speak with you and against the threat that seeks to silence political speech" The BDS campaign has provided a context for this collective action.

In 2005, over one hundred groups drawn from "Palestinian political parties, unions, associations, coalitions and organizations" representing "Palestinian refugees, Palestinians under occupation and Palestinian citizens of Israel" issued a call on behalf of Palestinian civil society that "international civil society organizations and people of conscience all over the world [...] impose broad boycotts and implement divestment initiative against Israel similar to those applied to South Africa in the apartheid era" (Anon, 2005). For academics this has been taken to mean that one should not accept invitations to speak at Israeli state institutions insofar as those institutions are not identified with calls to end the Occupation. This has required of many academics some painful choices and reflections and the distinction between boycotting institutions and boycotting individuals has not always been clearly drawn, and to be fair it is sometimes very difficult to make these distinctions.

Butler has been exemplary in her support of others working out how to respond to this call. For example, when, in 2006, Slavoj Žižek was invited to the Jerusalem Film Festival, where a film about him was to be screened and to which he was also asked to 
speak about Udi Aloni's film, Forgiveness (Mecbilot), the boycott campaign asked that Žižek not go to the festival. Aloni notes that Žižek asked Butler's advice and that her suggestion was "that he speak about the film without being a guest of the festival. $\mathrm{He}$ gave back the money and announced that he was not a guest" but went to Jerusalem and spoke about Aloni's film (Aloni, 2010). On this occasion, he also went with Aloni to speak about the film together with Palestinian intellectuals in Ramallah (Alexander, 2011). Žižek has remained engaged with Jewish issues and along with Butler, and Alain Badiou, he contributed to Aloni's collection on Binational Israel (Aloni, 2011).

In November 2009, Sarah Schulman was invited to Israel to speak to the Israeli Lesbian and Gay Studies Conference at Tel Aviv University. She had previously indicated that she would be willing to go but now decided that she should educate herself about the issues involved in accepting the invitation. So she wrote to Butler: "Knowing I was looking to her for guidance, Butler got back to me in four hours with many concrete leads and suggestions. Read this, read that, find out about this person, find out about that. [...] She never told me what to do" (Schulman, 2012, page 28). Schulman also wrote, at Butler's suggestion, to an Israeli LGBT activist, Dalit Baum, who commented that the boycott was "a clear and valid request from a wide range of groups representing a people under extreme and violent repression," proposing that instead of visiting Tel Aviv University Schulman could make a solidarity visit and speak at alternative "grassroots or Palestinian venues and use your visit to learn and teach by meeting the communities and speaking about it later abroad," and concluding that "the academic boycott is really an education tool" encouraging people to think about all sorts of implications heretofore ignored (Schulman, 2012, page 29). Schulman took this advice. Like Žižek, Schulman too has continued to engage with Jewish issues and wrote a New York Times op-ed, "Israel and 'Pinkwashing," on the misleading way that supporters of Israel claim that tolerance of gays and lesbians in the country shows its democratic 
superiority (Schulman, 2011). In her book, Israel/Palestine and Queer International, Schulman reflects upon the broader politics of solidarity movements.

The injunction to consider the call for a boycott was in both these cases productive of a closer engagement with Jewish issues, with critics of Israel from inside the country, and with Palestinian activists and intellectuals. Both Žižek and Schulman were given crucial support by the example and the direct advice of Butler and both garnered significant publicity for the Boycott movement by their decisions to respect its call. Butler, Žižek, and Schulman have also reflected upon what the boycott movement can most productively and ethically request and in developing their own practice in conversation with others they contribute to a social movement based upon solidarity rather identity and yet Schulman found herself reflecting that it was mainly to other Jews that she turned for advice and Butler has herself taken up Jewish thinkers in her most recent interrogation of the resources with which we might think about how to give proper recognition to the desires of others.

\section{Thinking with the Diaspora}

In Giving an account of oneself, Butler considers the work of Emmanuel Lévinas (1906-95), and makes evident the racist geopolitics behind Lévinas' representation of this interpersonal encounter between Self and Other. The face of the Other confronts us with a humanity we recognize because we are able to empathetically occupy the position of this other person, and then understand the demands they might make as proceeding from a humanity rather like our own. We are also able to appreciate that our own vulnerability to injury at the hands of the Other is very like our capacity to, and thus responsibility to choose not to, inflict injury upon the other person. The responsibility is unavoidable for, in Butler's summary, "I cannot disavow my relation to the Other" (Butler, 2005, page 91). 
However, Lévinas not only drew upon Talmudic scholarship in elaborating his argument, he also made problematic reference to Jewish history. His argument was that the Jewish people are characterised by a willingness to accept an undeserved harm rather than be responsible for harming their Other. Lévinas also conflates Israel as a state with Israel as a Jewish people. Thus he can suggest that Israel is characterized by persecution, that Christian Europe understands ethical relationality because it has been implicated in and has long observed this Jewish relationship to suffering. On the other hand, no such ethical relationality has characterized the Asian, or "exotic" cultures. In 1960, Lévinas wrote of the support given during the Holocaust to Jewish people by French clergy and suggested that this "has created a reconciliation with Christians and Christian groups" (Lévinas , 1990, page 163). Lévinas situates the Jewish people as producing in Christian Europe a recognition of suffering and persecution that grounds an ethical relationship between peoples. But outside Europe, there are peoples who lack this lesson in civilization and, for example, this was why Lévinas was so disturbed by the orientation of the Soviet Union towards China and away from Europe. For Russia, there was, he warned, a "spiritual" "yellow peril" with the danger of "drowning in an Asian civilization" (Lévinas, 2004, page 108). In Parting Ways: Jewishness and the Critique of Zionism, Butler takes further her engagement with Lévinas noting that he treated the Asiatics, Africans, and Arabs as faceless masses, who in their hunger, neediness, materialism, and barbarism may swamp Jewish/European civilization. Butler's (2012c, page 48) conclusion is that: "Here we can see the Ashkenazi presumption that [...] substantive Jewish history is the history of European Jewry, and not the Sephardim (descended from the Jews in Spain and Portugal) or the Mizrachim (descended from North African and Arab Jewish cultures)." Her argument is that a racist geopolitics prevents Lévinas from seeing in the Arab neighbours of Israel the human face that he 
had made such a powerful occasion for reflection in his own more abstract writings about ethics.

The treatment of Jewish people within Europe, with pogroms, expulsions, occasional emancipations, and then the genocidal crime of the Holocaust has meant that thinking about the "Jewish Question" has been at the root of much European philosophical speculation about the nature of modernity and the of West. Yet, all too often the category "Jew" is used, implicitly and explicitly, without any sensitivity to the claims upon its use that a reasonable reading of this painful history should impose. In her brilliant study of French post-Heideggerian philosophy, Elizabeth Bellamy (1997) castigated many French philosophers for not recognising the ways that the silence of Paul de Man (1919-83) and of Martin Heidegger (1889-1976) about the extremity of Jewish suffering and the failure of philosophers such as François Lyotard (1924-88) to acknowledge fully the causes and nature of that silence has meant that when they in turn have taken up issues relating to the place of the "Jew" in European thought their discussions are over-burdened with their own repression of the appalling anti-Semitism of Heidegger and de Man. This necessary movement between history and philosophy is central to Butler's own engagement with Jewish thinkers in Parting ways.

Butler chooses to think alongside thinkers from the Jewish diaspora: Walter Benjamin (1892-1940), Hannah Arendt (1906-75), and Primo Levi. She is trying "to delineate a political ethics that belongs to the Diaspora, where Jews are scattered among non-Jews, and to derive a set of principles from that geographical condition and transpose them onto the geopolitical reality of Israel/Palestine" (Butler, 2012c, page 99). Her point of departure is the violence that often grounds demotic nationalism. To produce one people for one place, some other peoples are frequently expelled from that national space, or are subjugated within it. Benjamin (1996, pages 248-9) suggested that "the establishing of frontiers [...] is the primal phenomenon of all lawmaking violence." 
He recognized the ways that national stories must forget this oppression in order to claim for the national people those civilized virtues that justify their claims to selfgovernment, but Benjamin (2003a, page 392) also thought that these painful memories, "[t]he tradition of the oppressed," though repressed, could return and, unbidden, illuminate later moments of comparable state violence. Butler (2012c, page 99) "continue[s] to think about Benjamin in order to understand the right to wage public criticism against violence, but also to articulate the values of cohabitation and remembrance-the values of not effacing the active traces of past destruction." These traces are the luggage of the displaced. Against the idea that history is the genealogy of nation-states, Benjamin (2003b, page 406) proposed that "the notion that the history of humanity is composed of peoples is a mere refuge of intellectual laziness.” Butler draws upon Benjamin's profound reflections upon Jewish philosophies of history, to explicate the relations between violence and state formation. Benjamin played Greek against Jewish mythology, undercut historical materialism with Jewish theology and vice versa, and contrasted mythical with messianic time. These tactics allow Butler to join some other Jewish writers (including Boyarin and Boyarin, 1993; Raz-Krakotzkin, 2007) in unsettling the mythical basis of Zionist nationalism.

Hannah Arendt's work takes Butler to a more explicit engagement with Israel as a specific example of political nationalism. Yitzhak Laor (2012) was right about the Adorno Prize: "Butler is coming to Frankfurt in Arendt's footsteps." Nazi Antisemitism politicised Arendt and, rejecting an assimilation that failed to confront never mind check oppression, she spent much of the 1930s sympathetic to Zionism; emigration to a safe land seemed the best option for the Jewish people of Europe. Having left Germany for Paris in 1933, the German invasion of France drove her to the United States in 1940 and from there she provided a Jewish perspective on the war and on the creation of the state of Israel. 
In her brilliant analysis of the modernity of the Nazi state, Arendt (1958, page 275) noted the identification of the state with a people as a crucial deformation of human rights, a "transformation of the state from an instrument of the law into an instrument of the nation." When, in 1944, she saw the Zionist movement plan for a "Jewish commonwealth" over "the whole of Palestine," she was appalled because it offered Arabs there "the choice [only] between voluntary emigration or second-class citizenship" (Arendt, 2007a, page 343). On this basis, the new state would ever be at war with its Arab neighbours and would have to mortgage its sovereignty to whichever superpower was willing to defend it against those neighbours. Arendt wanted, not a Jewish state, but a Jewish homeland alongside and among Arab peoples and for this reason she wanted "mixed Jewish-Arab municipal and rural councils" (Arendt, 2007b, page 401). In 1948 Arendt (2007c, page 410) was particularly critical of what she described as terrorist actions against Arab peoples and, with Albert Einstein among others, sent a letter to the New York Times decrying support in the US for Menachem Begin's (1913-92) Freedom Party, which the letter described as the "latest manifestation of fascism." Arendt celebrated, instead, those "nonnationalist trends in Jewish tradition," such as sustained the collective settlements and the Hebrew University within Israel (Arendt, 2007d, page 441). It is notable that current discussion of binational accommodations for the Jewish and Palestinian peoples within Israel/Palestine returns to Arendt's legacy (Miller, 2012; Raz-Krakotzkin, 2011), and that her Origins of Totalitarianism received its first Hebrew translation in 2010 (Arendt, 2010; Avineri, 2010).

Arendt (1958, page 298) tried to find ways that the Jewish experience of diaspora, of pariah status, as refugees, and even of persecution, might help Jewish people stay connected to the non-national values of human rights, "the right to have rights," something granted to people, as humans, by other humans, and thus not as a gift of states. For Butler and Arendt, this non-chauvinist understanding of rights is an 
unavoidable consequence of our necessary sociality (Dikeç, 2012; Owens, 2012). In her discussion of the "Jew as pariah," Arendt (2007e, pages 296-7) acknowledged the heroism of Kafka's attempt to craft an ethic of the "simple, decent life," even under unfair treatment, yet, she concluded that life as an isolated person of goodwill was simply too exhausting to be viable for "only when a people lives and functions in consort with other peoples can it contribute to the establishment upon earth of a commonly conditioned and commonly controlled humanity." In Eichmann in Jerusalem, Arendt (1994, page 279) described the Nazi crime against humanity as "a policy of not wanting to share the earth with the Jewish people $[\ldots]$ as though you and your superiors had any right to determine who should and who should not inhabit the world."

In Parting ways, then, Butler develops her criticisms of Zionist nationalism and her defence of the boycott movement in conversation with the legacy of the Jewish writings of figures from the Diaspora. For each of them, their Jewishness was a matter of comment among their Jewish critics. In 1948, Arendt was attacked for suggesting that the Jewish people of Israel should try to cooperate with Britain and the Arab countries in developing international security for Israel. The term that was used to describe her position had unwelcome resonances from the Second World War: "The term 'collaborationist is, of course, a defamation" (Arendt, 2007f, page 415).

\section{The Lessons of Genocide}

Butler takes up the question of Holocaust memory in her discussion of Primo Levi, an Auschwitz survivor. Levi says that he was "was turned into a Jew by others. [...] The experience of the Race Laws [1938] helped me to recognize, amongst the many threads that made up the Jewish tradition, a number I could accept” (Bruck, 2001, page 262). This recuperation had an agenda and, with a group of young Jewish friends, he took up "the task of showing how the Bible and Fascism were incompatible, so that a Jew could 
only be anti-Fascist. Our tendentious or at least rather rough-hewn project was this, to search out in the Torah, the Pentateuch, all those episodes that proved that justice and liberty were fundamental aspects of Jewish culture" (De Leca and Olanger, 2001, page 164). The Jewish tradition gave Levi ways to be an opponent and not merely a victim of Fascism.

Arrested as a partisan and sent as a Jew to Auschwitz by the Germans, Levi (1987, page 168) struggled to comprehend this "anus mundi, ultimate drainage point of the German universe." Giving an account was at the core of Levi's humanity and he said that both in the camp and afterwards "understanding and being understood was of fundamental importance" (Toaf and Ascarelli, 2001, page 214). In Auschwitz, Levi (1959, pages 99-100) tried treating the camp as "pre-eminently a gigantic biological and social experience" which might have been "set up to establish what is essential and what adventitious to the conduct of the human animal in the struggle for life." He did not have an ultimate, or final, explanation of the extermination: "I can't answer the whys" (Bravo and Cereja, 2001, page 245). He mistrusted claims to final explanations seeing such certainty as one half of the Nazi madness. The hubris of fascist Germany was dehumanizing. In Buna-Monowitz, the sub-camp of Auschwitz where Levi was kept with some 10,000 other forced labourers, they looked up at the Carbide Tower "built by us $[\ldots$ and $]$ cemented by hate $[\ldots]$ like the Tower of Babel $[\ldots]$ and in it we hate the insane dream of grandeur of our masters, their contempt for God and men, for us men" (Levi, 1959, page 81). These dreams of grandeur must be resisted: “It is better to renounce revealed truths $[\ldots]$. It is better to content oneself with other more modest and less exciting truths, those one acquires painfully, little by little and without shortcuts, with study, discussion, and reasoning” (Levi, 1979, page 396).

Hubris fed inhumanity. The second chapter of If This is a Man tells how, on their first night at Auschwitz, the inmates recognized that they had been brought as low as 
humans could be brought: " $[\mathrm{N}]$ o human condition is more miserable than this $[\ldots]$. Nothing belongs to us anymore; they have taken away our clothes, our shoes, even our hair" (Levi, 1959, page 21). Such a person was "hollow [...], reduced to suffering and needs, forgetful of dignity and restraint, [... a person] whose life or death can be lightly decided with no sense of human affinity" (Levi, 1959, pages 21-2). In other words, with so little of the human left, the life can be taken with less guilt.

The lesson is clear: "It happened, therefore it can happen again" (Levi, 1989, page 167). Even while he was in Auschwitz, Levi was drafting a poem based on the Judaic Shemà, a prayer in which the Jewish people are told to love and serve their God, to bind their children to do likewise, and to foreswear all other gods for fear that their God will withdraw from them the bounty of Nature. Levi's (1988) prayer is addressed to "You who live secure | In your warm houses," forcing them to recognize the humanity even in "a man, | Who labors in the mud | [...] Who dies at a yes or a no," demanding that they "Consider that this has been" and in the face of these facts "Repeat them to your children. | Or may your house crumble, | Disease render you powerless, | Your offspring avert their faces from you." Levi was particularly pained by the development in France during the 1970s of even modest respect for skepticism about the reality of the Nazi extermination camps, and in Germany in the 1980s of an attempt to reduce the singularity of the exterminations by loose comparison with diverse crimes against humanity and specious attempts to spread blame beyond Germany (Angier 2002). Levi's concern was urgent: "[T] o deny Auschwitz is to be ready to rebuild it" (Toaf and Ascarelli, 2001, page 217).

Israel's war in South Lebanon (6 June 1982-17 May 1983) and its responsibility for the associated massacres at the refugee camps of Sabra and Shatila (16-18 September 1982) caused Levi acute anguish. He accepted, in broad terms, the Zionist case for a state that would always welcome Jewish immigrants, "the sanctuary to which Jews threatened 
in other countries would be able to run" (Carmon, 1989, page 54). He professed a "sentimental tie with Israel, if for no other reason than it was built by us, by my fellow prisoners" (Carmon, 1989, page 56). But contemplating Israel in 1982, he was led, as had been Arendt in 1948, to castigate Menachem Begin in the strongest terms: "“Fascist' is a definition I can accept" (Pansa, 2001, page 282). He was angered that Begin used as alibi for his expansionist wars, the fact that Israel was the sanctuary for survivors of the Nazi extermination camps: "I deny any validity to that defence" (Pansa, 2001, page 286).

Butler appreciates Levi's Diasporic defence of tolerance: “[e]very Jew has the right and duty to choose his position: religious or non-religious, pro-Israel or anti-Israel" (Carmon, 1989, page 56). He argued that "the best of Jewish culture is bound to the fact of being dispersed, polycentric," and that the Diaspora is a place of "interethnic exchange and relations, in other words a school for tolerance” (Lerner, 2001, pages 2912). This is about an historical geography that produces a distinct geopolitics of identity. The idea that the time-space envelope of an identity may be given as one nation in one state continuously is a dangerous myth for Jewish as for other identities. Such a myth is often called upon to legitimate identities but it not only does violence to the multiple claims upon territory but also to the imperatives of geographical instability. As Butler (2012c, page 8) suggests: "What gives a tradition legitimacy is very often what works against its effectiveness. To be effective, a tradition must be able to depart from the particular historical circumstances of its legitimation and prove applicability to new occasions of time and space." This means that the resources of tradition must travel.

The Diasporic reading of Jewish identity offers resources for thinking about how to live alongside different Others. This living-alongside must be non-exclusive both with regard to the historical significance of place for identity and with regard to the geographical roots and routes of current place-based claims. Many stories are gathered-in to any one place, and many traditions make claims upon the fabric and signification of 
any one place. The resources of tradition must accommodate. Butler (2012c, page 8) remarks that "such resources can only become effective by losing their grounding in historical or textual precedent, which means that only by 'ceding ground' does an ethical resource from the past come to thrive elsewhere and anew, in the midst of converging and competing ethical claims, as part of a process of cultural translation that is also a remapping of social bonds or indeed of geographical space itself.”

\section{The Geopolitics of Identity}

These geographies of social bonds may be freely acknowledged but they are not freely chosen and they are generally asymmetrical. Connections between people in different places are overlain by asymmetries of power and interest. For some Jewish people in Germany, that a German city could contemplate rewarding a critic of Israel was unforgivable. Matthias Küntzel, a political scientist, found it strange "that Frankfurt of all cities should honor her [...]-Frankfurt, a center of Judaism in Germany and a city where the Nazi boycott of Jews is still remembered" (Landes, 2012).

There are some few academics in Israel who have endorsed the BDS campaign. In August 2009, Neve Gordon (2009), a political scientist at Ben-Gurion University (BGU), wrote in the Los Angeles Times that he thought the boycott was "the only way that Israel can be saved from itself." With respect to the land Israel occupied in 1967, Gordon (2009) wrote that it now contained 3.5 million Palestinians and almost half a million Jewish people but that they were "subjected to totally different legal systems. The Palestinians are stateless and lack many of the most basic human rights. By sharp contrast, all Jews-whether they live in the occupied territories or in Israel-are citizens of the state of Israel." After more than forty years of this situation, Gordon thought that without significant external pressure, there was no prospect of reaching either of what he sketched as the two possible solutions, that Israel should withdraw to its pre-1967 limits 
or that it should grant full citizenship to all Palestinians within the territory it currently controlled.

The response from the United States was immediate. Nurit Greenger, born in Haifa and living in Beverly Hills, encouraged other supporters of Israel to switch their donations from BGU to other Israeli "educational institutions that hold strong Zionist sentiments” (Russo, 2009). Disaffected Friends of BGU lobbied Israel's Consul-General in Los Angeles who told Rivka Carmi, president of BGU, that these US residents "were unanimous in threatening to withhold donations from your institution” (Russo, 2009). Within a fortnight of Gordon's op-ed, Carmi responded with one of her own in the same US newspaper. She attacked Gordon’s remarks as “demagoguery cloaked in academic theory" and suggested that Gordon's "Israeli-bashing" would invite a "collective punishment" upon the University which would imperil its "many Israeli-Arab collaborations" (Carmi, 2009). Gordon did not accept her invitation to resign.

In a further turn of the screw, when Israel's Council for Higher Education (CHE) commissioned an international review of political-science and internationalrelations departments it did so under the direction of a Minister of Education, Gideon Sa'ar, who had already called Gordon's op-ed "repugnant and deplorable” (Ravad, 2009). Sa'ar also endorsed as "expressing an authentic public mood" the work of an activist group, Im Tirtzu, dedicated to monitoring what it views as anti-Zionist activity on campuses (Nesher, 2012). In July 2010 Im Tirtzu accused the Department of Political Science at BGU of working "deliberately and energetically to promote fiercely antiZionist messages" and it threatened to work for a boycott of BGU if this "anti-Zionist tilt" were not corrected (Kashti, 2010). In October 2010, it appears that some members of the CHE Committee rejected one of their members, Ian Lustick, Professor of Political Science at the University of Pennsylvania, as "too left-wing on Israel," whereupon the Committee chair, Robert Shapiro, Professor of Political Science at Columbia University, 
resigned (Nesher, 2011). In November 2010, Im Tirtzu and the Institute for Zionist Strategies were invited to speak to a special hearing of the Knesset Education Committee on "The Exclusion of Zionistic Positions in Academia" (Navon, 2010). A member of the Institute for Zionist Strategies was a member of the CHE committee.

Later in November 2010 the CHE committee was reformed under a new chair, a Political Scientist from Germany, and in September 2011 it issued its report on the Department of Politics and Government at BGU finding the Department too interdisciplinary and insufficiently positivist for the taste of the committee and too radical for the taste of some of BGU's students (Anon, 2011). These relations between CHE and extremist pressure groups provided the context in which Gordon's department at BGU was effectively pilloried for the politics of some faculty, and not for any evident failures of scholarship; indeed, in comparative and formal terms the Department seemed to be productive and successful (Isacademyunderattack, 2012). BGU appealed the September 2012 recommendation of the CHE Sub-Committee for Quality Assessment that, as of Summer 2013, BGU should not be allowed to admit new students in the Department of Politics and Government, and, after a long stay of execution, that threat was lifted finally in February 2013 (Nesher, 2013).

A striking feature of this latest episode in the academic geopolitics of the BDS campaign is that the pressure groups in Israel providing the ammunition for attacks on academics, either anti-Zionist or judged incompletely Zionist, closely follow the tactics of comparable groups in the US, such as Daniel Pipes' Campuswatch (McClennen, 2006). There is a geopolitical content to this monitoring since Pipes not only broadcasts claims about the anti-Israeli stance of named academics but he has found supporters within the US Congress who have introduced similar monitoring as part of the review of the allocation of government funds to Area Studies programmes at universities (Schueller, 2007). When Judith Butler spoke in favour of the BDS at Brooklyn College, New York, 
Alan Dershowitz denounced this as "a violation of academic freedom" and ten members of New York City Council called for the defunding of such "schools whose programs we, and our constituents, find to be odious and wrong" (Dershowitz, 2013; Anderson, 2013). Conservative Jewish figures in the US are important sponsors of Israeli universities in general but these watchdog efforts receive significant support in addition from Christian groups, such as Christians United for Israel, for whom war in the Middle East and the triumph of Israel will announce the Second Coming of Christ (Blau, 2011; see also Dittmer, 2008). That the evangelical geopolitics of the End Times can inflect how Jewish identities are negotiated in the context of a boycott requested by Palestinian civil society confirms the mutual constitution of biopolitics and social movements that Butler has done so much to illuminate and explain.

\section{Acknowledgements}

I want to thank Karen Till, David Nally, John Morrissey, Derek Gregory, Alistair Fraser, and Michael Brown for earlier comments. I must also thank the Editorial Board and the referees for constructive reviewing. Most of all, thank you to Stuart Elden for helping with this paper and for exemplifying the civility and responsibility that makes good editing such a service to the academic community.

\section{References}

Adorno T W, 1991 "Resignation" translated by W Blomster, in Theodor W. Adorno, The Culture Industry: Selected Essays on Mass Culture Ed. J M Bernstein (Routledge, London) pp 198-203; first published in 1969

Alexander N, 2011 “Cinema verité” Haaretz, 15 July, http://www.haaretz.com/weekend/magazine/cinema-verite-1.373397 
Aloni U, 2010 "Judith Butler: As a Jew, I was taught it was ethically imperative to speak up" Haaretz, 24 February, http://www.haaretz.com/news/judith-butler-as-a-jew-i-wastaught-it-was-ethically-imperative-to-speak-up-1.266243

Aloni U, 2011 What Does a Jew W ant?: On Binationalism and Other Specters (Columbia University Press, New York)

Anderson J, 2013 "Amid criticism, college says event on Israel can proceed” New York Times, 5 February, page A21

Angier C, 2002 The Double Bond: Primo Levi, a Biography (Farrar, Straus and Giroux, New York)

Anon, 2005 "Palestinian Civil Society Call for BDS, 9 July", http://www.bdsmovement.net/call

Anon, 2011 Committee for the Evaluation of Political Science and International Relations Programs, Ben Gurion University. Department of Politics and Government. Evaluation Report. September 2011, http://www.scribd.com/doc/74235533/BGU-Report

Anon, 2012 "No Adorno award for Anti-Semite Judith Butler", http://www.change.org/petitions/no-adorno-award-for-judith-butler-no-adorno-awardfor-anti-semites

Arendt H, 1958 The Origins of Totalitarianism 2nd edition (World Publishing Company, New York)

Arendt H, 1994 Eichmann in Jerusalem: A Report on the Banality of Evil (London: Penguin, London); first published 1963

Arendt H, 2007a "Zionism reconsidered", in Hannah Arendt. The Jewish Writings Eds J Kohn, R H Feldman (Schocken Books, New York) pp 343-374; first published 1944 Arendt H, 2007b "To save the Jewish homeland", in Hannah Arendt. The Jewish Writings Eds J Kohn, R H Feldman (Schocken Books, New York) pp 388-401; first published 1948 
Arendt H, 2007c "New Palestine party", in Hannah Arendt. The Jewish Writings Eds J

Kohn, R H Feldman (Schocken Books, New York) pp 417-419; first published 1948 Arendt H, 2007d "Peace or armistice in the Near East", in Hannah Arendt. The Jewish Writings Eds J Kohn, R H Feldman (Schocken Books, New York) pp 423-450; first published 1950

Arendt H, 2007e "The Jew as pariah: A hidden tradition", in Hannah Arendt. The Jewish Writings Eds J Kohn, R H Feldman (Schocken Books, New York) pp 275-297; first published 1944

Arendt H, 2007f “About collaboration”, in Hannah Arendt. The Jewish Writings Eds J Kohn, R H Feldman (Schocken Books, New York) pp 414-416; first published 1948 Arendt H, 2010 Yesodot Hatotalitariut [The Origins of Totalitarianism] second edition, translated I Zertal (Hakibbutz Hameuchad Publishing House, Tel Aviv); first published 1958

Avineri S, 2010 “Where Hannah Arendt went wrong” Haaretz, 3 March, http://www.haaretz.com/where-hannah-arendt-went-wrong-1.264075 Bellamy E J, 1997 Affective Genealogies: Psychoanalysis, Postmodernity, and the "Temish Question" after Auschwitz, (University of Nebraska Press, Lincoln NE)

Benjamin W, 1996 “Critique of violence” translated E Jephcott, in Walter Benjamin. Selected Writings. Volume 1. 1913-1926 Eds M Bullock, M W Jennings (Belknap Press, Cambridge MA) pp 236-252; first published 1921

Benjamin W, 2003a "On the concept of History" translated H Zohn, in Walter Benjamin. Selected Writings. Volume 4. 1938-1940 Eds H Eiland, M W Jennings (Belknap Press, Cambridge MA) pp 389-400; first published 1940

Benjamin W, 2003b "Paralipomena to "On the concept of History" translated E Jephcott and H Eiland, in Walter Benjamin. Selected Writings. Volume 4. 1938-1940 Eds H Eiland, M W Jennings (Belknap Press, Cambridge MA) pp 401-411; first published 1940 
Blau U, 2011 "Major Israeli business helped quadruple donations to right-wing Im Tirtzu movement" Haaretr, 30 December, http://www.haaretz.com/weekend/magazine/major-israeli-businesses-helpedquadruple-donations-to-right-wing-im-tirtzu-movement-1.404637\#

Boyarin D, Boyarin J, 1993 "Diaspora: Generation and the ground of Jewish identity" Critical Inquiry 19(4) 693-725

Bravo A and Cereja F, 2001 “The duty of memory" translated R Gordon, in Primo Levi. The Voice of Memory, Interviews 1961-87 Eds M Belpoliti, R Gordon (Polity, Cambridge UK) pp 218-249; first published 1983

Bruck E, 2001 "Jewish, up to a point” translated R Gordon, in Primo Levi. The Voice of Memory, Interviews 1961-87 Eds M Belpoliti, R Gordon (Polity, Cambridge UK) pp 261265; first published 1976

Butler J, 1997a Excitable Speech: A Politics of the Performative (Routledge, London)

Butler J, 1997b The Psychic Life of Power: Theories in Subjection (Stanford University Press, Stanford CA)

Butler J, 1999a Gender Trouble: Feminism and the Subversion of Identity (Routledge, New York); first published 1990

Butler J, 1999b "Preface", in Gender Trouble: Feminism and the Subversion of Identity J Butler (Routledge, New York) pp vii-xxvi

Butler J, 2003 “No, it's not anti-semitic” London Review of Books 25(16) http://www.lrb.co.uk/v25/n16/judith-butler/no-its-not-anti-semitic Butler J, 2004a Precarious Life: The Powers of Mourning and Violence (Verso, London) Butler J, 2004b Undoing Gender (Routledge, London)

Butler J, 2005 Giving an Account of Oneself (Fordham University Press, New York) Butler J, 2010a Frames of War: When is Life Grievable? (Verso, London); first published 2009 
Butler J, 2010b "Introduction to the paperback edition", in Frames of War: When is Life Grievable? J Butler (Verso, London) pp ix-xxx

Butler J, 2012a "Can one lead a good life in a bad life? Adorno Prize Lecture" Radical Philosophy 76 9-18

Butler J, 2012b Subjects of Desire: Hegelian Reflections in Twentieth-century France (Columbia University Press, New York); first published 1987

Butler J, 2012c Parting Ways: Jewishness and the Critique of Zionism (Columbia University Press, New York)

Carmi R, 2009 “Neve Gordon’s divisive op-ed” Los Angeles Times 1 September, http://articles.latimes.com/2009/sep/01/opinion/oe-carmi1

Carmon F, 1989 Conversations with Primo Levi translated J Shepley (Marlboro Press, Marlboro VT); first published 1987

City of Frankfurt, 2012 "Judith Butler mit dem Theodor-W.-Adorno-Preis des Jahres 2012 ausgezeichnet",

http://www.frankfurt.de/sixcms/detail.php?id $=2855 \&$ ffmpar $\% 5 \mathrm{~B}$ id inhalt $\% 5 \mathrm{D}=110$ $\underline{67274}$

Debrix, F, 2011 “Rethinking democracy’s emergence: Toward new spaces of grief and survivability" Environment and Planning D: Society and Space 29 369-374

De Leca R C, Olagner M, 2001 “Primo Levi” translated R Gordon in Primo Levi. The Voice of Memory, Interviews 1961-87 Eds M Belpoliti, R Gordon (Polity, Cambridge UK) pp 161-166; first published 1984

Derrida J, 1992 "Before the Law" translated A Ronell, C Roulston, in Jacques Derrida, Acts of Literature Ed. D Attridge (Routledge, London) pp 182-220; first published 1982 Dershowitz A, 2013 “Brooklyn College's anti-Israeli hatefest” New York Daily News, 30 January, http://www.nydailynews.com/opinion/brooklyn-college-anti-israel-hatefest$\underline{\text { article-1.1250553 }}$ 
Dikeç M, 2012 "Politics is sublime" Environment and Planning D: Society and Space $30262-$ 279

Dittmer J, 2008 “The geographical pivot of (the end of) history: Evangelical geopolitical imaginations and audience interpretation of "Left Behind" Political Geography 27(3) 280300

Eban A, 1973 "Our place in the human scheme" Congress Bi-Weekly, 30 March, 5-9

Eban A, 1975 "Zionism and the UN" New York Times 3 November, page 35

Ellouz E, 2012 “Judith Butler gets a taste of her own politics” Haaretz 20 September, http://www.haaretz.com/weekend/magazine/judith-butler-gets-a-taste-of-her-ownpolitics-1.465861

Foucault M, 1990 The History of Sexuality. Volume I: An Introduction translated R Hurley (Vintage Books, New York); first published 1976

Gordon N, 2009 “Boycott Israel” Los Angeles Times 20 August, page A31

Isacademyunderattack, 2012 "Inaccuracies and fallacies of the report submitted by the International Evaluation Committee on the department of politics and government" Israeli Academia Under Attack 18 September, http://isacademyunderattack.wordpress.com/2012/09/18/inaccuracies-and-fallacies-ofthe-report-submitted-by-the-international-evaluation-committee-on-the-department-ofpolitics-and-government/

Joffe A, 2012 “Adorno, Butler, and the death of irony” Jewish Ideas Daily 28 September, http://www.jewishideasdaily.com/5087/features/adorno-butler-and-the-death-of-irony/ Kashti O, 2010 "Im Tirtzu threatens boycott of Israeli university over "anti-Zionist" bias" Haaretz, 17 August, http://www.haaretz.com/print-edition/news/im-tirtzu$\underline{\text { threatens-boycott-of-israeli-university-over-anti-zionist-bias-1.308452 }}$ Kearns G and Reid-Henry S, 2009 "Vital geographies: Life, luck and the human condition" Annals of the Association of American Geographers 99(3) 554-574 
Kuentzel M, Schumann R, Hansen N, Rensmann J, 2012 “SPME statement on awarding Judith Butler the "Adorno Prize," 15 August", http://spme.net/articles/8837/2/SPME$\underline{\text { Statement-on-awarding-Judith-Butler-the-Adorno-Prize.html }}$

Kundani H, 2009 Utopia or Auschwit?? Germany's 1968 Generation and the Holocaust

(Columbia University Press, New York)

Landes R, 2012 “Matthias Küntzel speaks at anti-Butler Rally in Frankfurt” The Augean Stables 18 September, http://www.theaugeanstables.com/2012/09/18/matthias-kuntzelspeaks-at-anti-butler-rally-in-frankfurt/

Laor Y, 2012 “In the spirit of Hannah Arendt” Haaretz 11 September, http://www.haaretz.com/opinion/in-the-spirit-of-hannah-arendt-1.464151

Lerner G, 2001 [1984] "If this is a state" translated R Gordon, in Primo Levi. The Voice of Memory, Interviews 1961-87 Eds M Bepoliti, R Gordon (Polity, Cambridge UK) pp 279296; first published 1984

Levi P, 1959 If This is a Man 2nd edition, translated S Woolf (Orion Press, New York); first published 1958

Levi P, 1979 “Afterword: The author's answers to his readers' questions” translated R Feldman, in If this is a man, The Truce P Levi (Penguin, London) pp 381-398); first published 1963

Levi P, 1987 "Story of a coin" translated R Feldman, in Moments of Reprieve (Abacus, London) pp 161-172; first published 1981

Levi P, 1988 “Shemà” translated R Feldman, B Swann, in Collected Poems P Levi (Faber and Faber, London) page 9; first published 1946

Levi P, 1989 The Drowned and the Saved translated R Rosenthal (Abacus, London); first published 1986 
Lévinas E, 1990 "Jewish thought today" translated S Hand, in Difficult Freedom: Essays on Judaism E Lévinas (Johns Hopkins University Press, Baltimore MD) pp 159-166; first published 1961

Lévinas E, 2004 “Dialectics and the Sino-Soviet Quarrel” translated N Poller, in Unforeseen History E Lévinas (University of Illinois Press, Champaign IL) pp 107-109; first published 1960

Marx K, 1973 [1852] "The Eighteenth Brumaire of Louis Bonaparte” translated B Fowkes, in Karl Marx: Surveys from Exile Ed. D Fernbach (Penguin, Harmondsworth UK) pp 143-249; first published 1852

McClennen S A, 2006 “Countering the assault on higher education” Radical Teacher 77 1519

Miller E, 2012 "What would Buber, Scholem and Arendt say today" Times of Israel 27 July, http://www.timesofisrael.com/what-would-buber-scholem-and-arendt-say-today/ Müller-Doohm S, 2005 Adorno: A Biography translated R Livingstone (Polity, Cambridge UK); first published 2003

Navon E, 2010 “Mount Scopus of Mount Olympus” Jerusalem Post 15 November, http://www.jpost.com/Opinion/Op-EdContributors/Article.aspx?id=195472 Nesher T, 2011 "International academics seek to keep "biased” department at Israeli university open" Haaretz 20 December 2011, http://www.haaretz.com/printedition/news/international-academics-seek-to-keep-biased-department-at-israeliuniversity-open-1.402450

Nesher T, 2012 "Education Ministry school program presents Gush Katif as the epitome of Zionism" Haaretz 20 February, http://www.haaretz.com/printedition/news/education-ministry-school-program-presents-gush-katif-as-the-epitome-ofzionism-1.413645 
Nesher T, 2013 “Israeli education body reverses decision to close Ben Gurion University politics department" Haaretz.13 February, http://www.haaretz.com/news/national/israeli-education-body-reverses-decision-to$\underline{\text { close-ben-gurion-university-politics-department.premium-1.503188 }}$

Owens P, 2010 "Walking corpses: Arendt on the limits and possibilities of cosmopolitan politics", in International Relations Theory and Philosophy: Interpretive Dialogues Eds C Moore, C Farrands (Routledge, New York) pp 72-82.

Pansa G, 2001 "Primo Levi: Begin should go" translated R Gordon, in Primo Levi. The Voice of Memory, Interviews 1961-87 Eds M Belpoliti, R Gordon (Polity, Cambridge UK) pp 279-296; first published 1982

Ravid B, 2009 “Education Minister slams Israeli lecturer's 'apartheid' op-ed” Haaretz 23 August, http://www.haaretz.com/news/education-minister-slams-israeli-lecturer-sapartheid-op-ed-1.282520

Raz-Krakotzkin A, 2007 “Jewish memory between Exile and History” Jewish Quarterly Review 97(4) 530-543

Raz-Krakotzkin A, 2011 'Jewish peoplehood, 'Jewish politics,' and political responsibility: Arendt on Zionism and partitions" College Literature 38(1) 57-74 Russo YM, 2009 “The battle of the boycotts” Jerusalem Post 26 September, http://www.campus-watch.org/article/id/8388

Schueller M J, 2007 “Area Studies and multicultural imperialism: The project of decolonizing knowledge" Social Text 25(1) 41-62

Schulman S, 2011 "Israel and "Pinkwashing" New York Times 22 November, page A13 Schulman S, 2012 Israel/ Palestine and the Queer International. (Duke University Press, Durham NC)

Sedgwick E K, 1985 Between Men: English Literature and Male Homosocial Desire (Columbia University Press, New York) 
Sedgwick E K, 1990 Epistemology of the Closet (University of California Press, Berkeley CA) Summers L, 2002 “Address at morning prayers, 17 September”, http://www.harvard.edu/president/speeches/summers 2002/morningprayers.php Toaff D, Ascarelli E, 2001 "Return to Auschwitz" translated R Gordon, in Primo Levi. The Voice of Memory, Interviews 1961-87 Eds M Belpoliti, R Gordon (Polity, Cambridge UK) pp 208-217; first published 1987.

UN, 1975 “Elimination of all forms of racial discrimination” United Nations, General Assembly, 30th Session Resolution 3379, A/RES/3379(XXX),

http://www.un.org/ga/search/view doc.asp?symbol=A/RES/3379(XXX)\&Lang=E\& $\underline{\text { Area }=\text { RESOLUTION }}$

UN, 2001 "Question of the Violation of Human Rights in the Occupied Arab Territories, including Palestine" United Nations Commission on Human Rights E/CN.4/2001/121, http://web.archive.org/web/20051202025015/http://www.unhchr.ch/Huridocda/Huri doca.nsf/TestFrame/19cfafb52ab5fc2bc1256a11005de32c?Opendocument UN, 2008 “OCHA-oPt Protection of Civilians, Summary Tables, October 2008” United Nations Office for the Coordination of Humanitarian Affairs, http://www.ochaopt.org/documents/POC Monthly Tables_October 2008.pdf Weinthal B, 2012a "Frankfurt to award US advocate of Israel boycott" Jerusalem Post 26 August, $\underline{\text { http://www.jpost.com/International/Article.aspx?id=282583 }}$

Weinthal B, 2012b “German Jewish leader: Rescind Israel hater's prize” Jerusalem Post 27 August, $\underline{\text { http://www.jpost.com/International/Article.aspx?id }=282790}$ 